
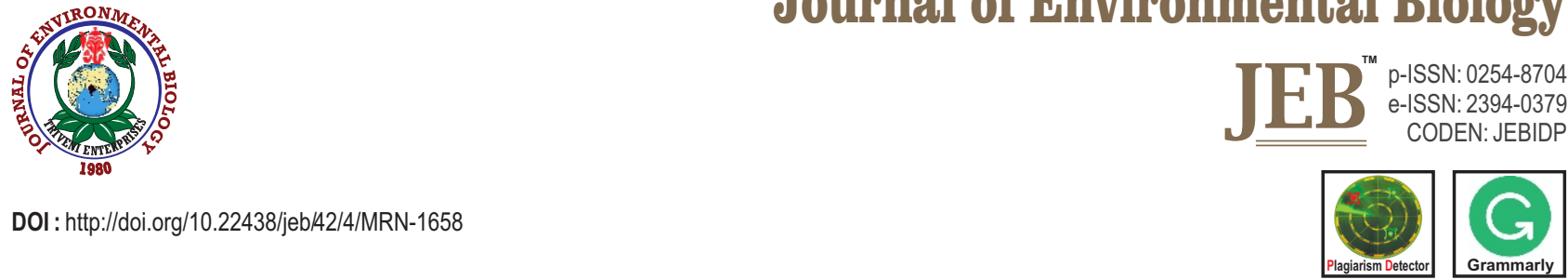

\title{
Neuroendocrine control of cocoon production in native earthworm Perionyx ceylanensis subjected to seasonal variation
}

\section{P.S. Chaudhuri* and R. Datta}

Earthworm Research Laboratory, Department of Zoology, Tripura University, Tripura-799022, India

*Corresponding Author Email : priya_1956@rediffmail.com

\section{Abstract}

Aim: The aim of the present study was to observe the role of cerebral ganglionic neurosecretory cells (NSCs) during cocoon production in native earthworm species Perionyx ceylanensis subjected to amputation and seasonal variations.

Methodology: Histological studies (using Aldehyde Fuchsin and Chrome Alum Haematoxylin Phloxin stain) were carried out on brain NSCs in the two groups of earthworms (Group I and Group II) maintained in earthen culture pots (2L) with cowdung as food. Group I comprised of brain amputed earthworms was subjected to observe the role of brain NSCs in production of cocoon and Group II earthworms subjected to seasonal changes in the cerebral NSCs during cocoon production. Five replications were kept for Group I (1 individual per pot) and Group II (1 pair per pot).

Results: Group I debrained earthworms started to lay cocoons from the $31^{\text {st }}$ day following regeneration of cerebral ganglionic type A NSCs. In group II worms the highest neurosecretory activity was registered in the cerebral type A cells, especially during monsoon coinciding with the hike of cocoon generation.

Interpretation: Appearance of type A NSCs in regenerated brain and peak of type A neurosecretory cell activity during peak reproductive period of earthworm species (as indicated by peak of cocoon production) indicates the possible role of cerebral type A NSCs in cocoon laying.

Key words: Amputation, Cocoon production, Neuroendocrine system, Neurosecretory cells, Perionyx ceylanensis

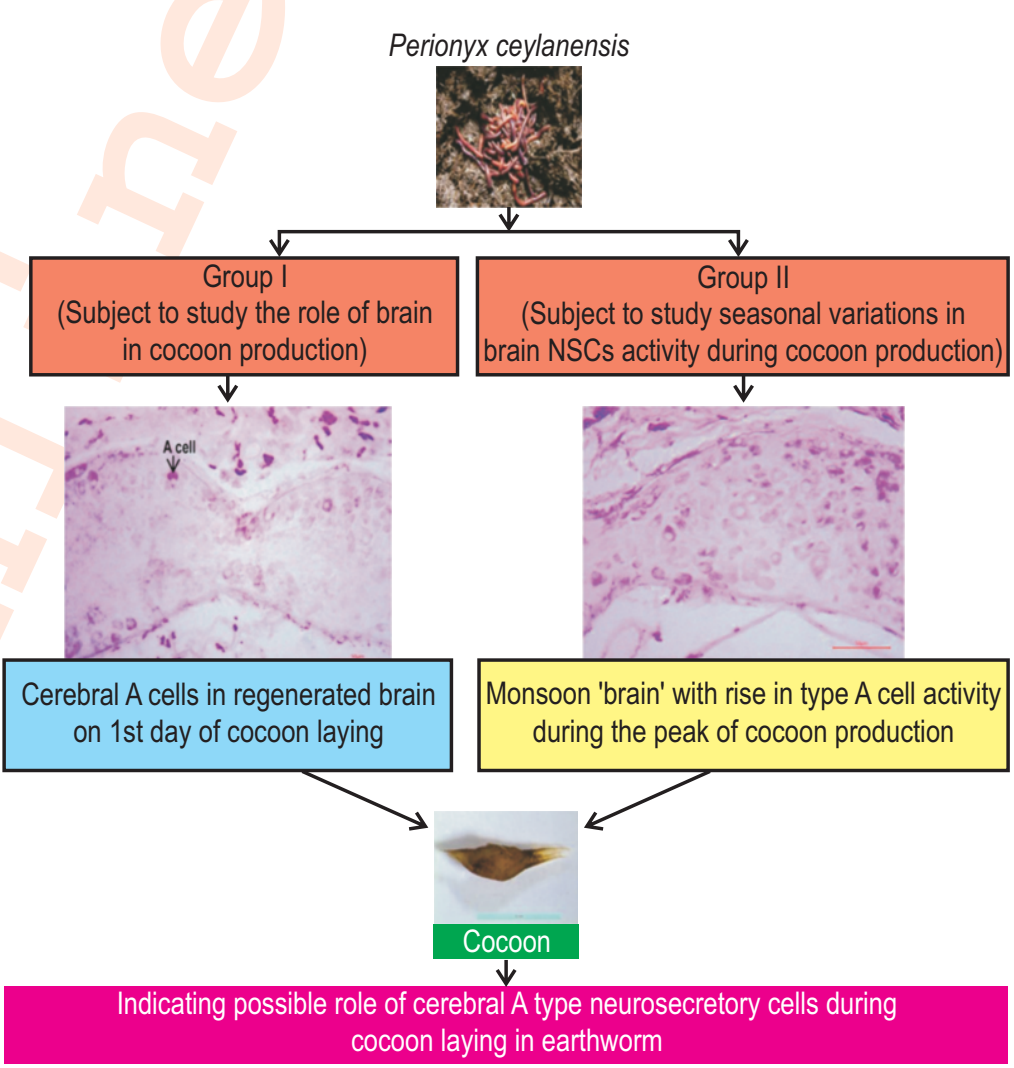

How to cite : Chaudhuri, P.S. and R. Datta: Neuroendocrine control of cocoon production in native earthworm Perionyx ceylanensis subjected to seasonal variation. J. Environ. Biol., 42, 930-937 (2021). 


\section{Introduction}

Earthworms are hermaphrodite, but practise cross fertilization (with some exceptions), thus receiving sperms during copulation (Cosín et al., 2011). Following copulation, which may take more than an hour, the worms separate and each clitellum produces a secretion from clitellar glands, which eventually hardens over the site of cocoon formation. Then the worms move backwards, drawing the tube over their heads. When the earthworm is completely free, the terminal ends of the tube close and forms a cocoon with the shape typical of each earthworm species (Bhattacharjee and Chaudhuri, 2002; Chaudhuri and Bhattacharjee, 2011). The cocoon contains a nutritive albuminous fluid produced by clitellar glands and the ova and spermatozoa which were discharged into it during copulation (Edwards and Bohlen, 1996). Fertilization, which occurs in the cocoon, is external. The wall of the cocoon consists of interwoven fibrils which are soft when first formed, but later becomes hard and very resistant to drying and damage (Edwards and Bohlen, 1996). The terminal ends of cocoons are extended into processes or tufts, which are of different forms basically depending upon the species. Size and shape of cocoon also differ among the species (Bhattacharjee and Chaudhuri, 2002; Chaudhuri and Bhattacharjee, 2011; Debnath and Chaudhuri, 2020; Chaudhuri and Datta, 2020).Recently, Chaudhuri and Datta (2020) reported that SEM studies of cocoon wall in Perionyx ceylanensis, which is extremely uneven due to the presence of interwoven fibrils. According to Karmegam and Daniel (2009), P. ceylanensis produces cocoon parthenogenetically and also by cross fertilization (despite of hermaphroditism).

The cocoons following hatching produce juveniles or 'baby worms' (Bhattacharjee and Chaudhuri, 2002). Number of cocoon produced by each earthworm per year, i.e. fecundity and the number of juveniles per cocoon also varies according to the earthworm species (Bhattacharjee and Chaudhuri, 2002; Chaudhuri and Datta, 2020). Earthworms along with their juveniles are utilized in the treatment of organic waste (vermicomposting technology). Detailed understanding of growth and reproductive biology of earthworm is essential to categorize the suitable earthworm species for in-situ and ex-situ earthworm technology (Chaudhuri, 2005).

Although, enormous research on the ecology, biology and vermicomposting technology of earthworms (Edwards et al., 2011; Chaudhuri, 2019; Debnath and Chaudhuri, 2020; Dhar and Chaudhuri, 2020) is available, but literature is scanty regarding the role of neuroendocrine system in earthworm reproduction. Absence of any well defined non- neural endocrine gland in earthworms (as in arthropods), the highly vascularized central nervous system (CNS) with an abundance of NSCs in oligochaetes act as a so-called neuroendocrine system that control various physiological activities such as growth, regeneration and reproduction (Tombes, 1970). Neurosecretory cells in the central nervous system (CNS) are the sole source of hormones in annelids in general and oligochaetes in particular. In fact, NSCs are special kinds of nerve cells, which are neuronal in structure and glandular in function. Distinct secretory rhythm with synthesis, release and transport of neurohormone from type $A$ and type B NSCs, particularly the A cells during active reproductive phase in Eudrilus eugeniae was advocated by Parthasarathi and Ranganathan (2000). The presence of gonadotropins in neurosecretions and their function on gametogenesis was earlier recorded in earthworm, Dendrobaena veneta by Siekierska (2002). According to Durchon (1967), brain plays a major role in secondary sex characteristics and egg laying in earthworms. Recently, Banik et al. (2020) studied the changes in cytomorpholgy of the cerebral neurosecretory system during copulation in epigeic earthworm, E. eugeniae. Although a very few reports are available on the neurohormonal influence in the gametogenesis in earthworms (Siekierska, 2002), till date information on the function of brain neurohormone in the process of cocoon laying in earthworms is lacking.

In light of the above, the aim of the present study was to study the role of brain and its NSCs in cocoon production in native epigeic earthworm, Perionyx ceylanensis based on brain extirpation and seasonal variations in NSCs activity.

\section{Materials and Methods}

Culture of earthworms: Earthworms, $P$. ceylanensis were cultured in a wooden box $(45 \mathrm{~cm} \times 30 \mathrm{~cm} \times 30 \mathrm{~cm})$ with partially decomposed cow dung, natural food for earthworms. Fresh food was given after every 15 days. The mean room temperature and humidity was $29.5^{\circ} \mathrm{C} \pm 0.52$ and $60.5 \% \pm 0.75$, respectively. Periodical sprinkling of water was done in order to maintain 70 $80 \%$ substrate moisture. As earthworms are photonegative, the wooden culture box was covered with a black cloth over an iron mesh supported by a wooden frame, so that the earthworms could be cultured in dim light.

Experimental design: Earthworms were broadly divided into two groups, i.e., Group I and Group II in order to determine the role of brain and its role NSCs in cocoon production. Group I was further subdivided into sub-group I (control: no amputation), sub-group II (anterior amputation: 5 anterior most segments amputed), subgroup III (posterior amputation: 5 posterior most segments amputed). All the sub-groups (each having five replications) were maintained in culture pots. Five adult and healthy clitellate earthworms of same age group were collected from laboratory stock culture for each sub group and reared in a $2 \mathrm{~L}$ earthen pot each having $300 \mathrm{~g}$ of partially decomposed cow dung. From the subgroup II, 5 earthworms were debrained by amputing five anterior most (cephalic) segments and from subgroup III five posterior most (caudal) segments were amputed by sterilized paragon knife. Amputed earthworms were kept in their respective culture pots. Then all the culture pots were studied carefully for 
their behavioral and physiological changes if any. Earthworm biomass and cocoon production were also recorded in each sub group. Cerebral ganglionic tissues were also taken from control, sub group II (regenerated cerebral ganglia) and sub group III (unoperated cerebral ganglia) immediately after cocoon laying and were fixed in Bouin's fluid for histological purpose. The study was terminated when both sub group II and subgroup III resumed their cocoon production.

To observe the histological changes during cerebral ganglia regeneration and histological features when it resumes its cellular activity for cocoon production after decerebration, 20 adult earthworms (more or less same age group) were 'debrained' and kept in a separate earthen pot having cow dung as food. Regenerated cerebral tissues were taken on $4^{\text {th }}, 10^{\text {th }}, 20^{\text {th }}$ and $31^{\text {st }}$ day and fixed in Bouin's fluid for histological purpose.

For the seasonal variations in the cerebral NSCs during cocoon production (Group II), one pair of earthworms was cultured in an earthen pot having 15 days old decomposed cow dung as food substrate(five replications were maintained). Cocoon production by the earthworm was recorded at an interval of three days throughout the year (2016-2017). There are mainly three seasons in a year i.e. monsoon (from July to October), summer (from March to June) and winter (from November to February). From stock culture earthworm, 'brain' tissues were taken every $30^{\text {th }}$ day of each month of a year for histological studies on the seasonal variations in cerebral NSCs with regard to cocoon production. Room temperature $\left({ }^{\circ} \mathrm{C}\right)$ was also recorded throughout the study.

Histology: Bouin's fixed cerebral ganglia were dehydrated and embedded in paraffin $\left(58^{\circ} \mathrm{C}-60^{\circ} \mathrm{C}\right)$. Serial sections $(7 \mu \mathrm{m})$ were stained with both simplified Aldehyde Fuchsin (AF) and Gomori's Chrome Alum-Haematoxylin Phloxin(CAHP) staining techniques following acid permanganate oxidation to demonstrate the different types of NSCs and to study variations in the activity of these cells. Photomicrographs were taken by using Bright Field Microscope (Dewinter). Activity of NSCs was determined by measuring the cellular $(n=20)$ and nuclear $(n=20)$ volume and calculating the necleocytoplasmic index $(\mathrm{NCl})$. The nuclear volume of NSCs was calculated by the formula: $\Pi d^{3} / 6$, where $d$ is the maximum diameter of nucleus measured with a calibrated ocular micrometer. The cellular volume was calculated by the formula: $4 / 3 a^{2} b / 8$, where $a$ and $b$ are the diameter ( $b$ cell length and a cell diameter). The $\mathrm{NCl}$ value was calculated by the formula: $N P=V n / V c-V n$, where $V n$ is the volume of the nucleus and $V c$ is the volume of the cell (Borrione et al., 1997).

Statistical analyses: Mean values were compared using Student's t-test (Zar, 1999) at 0.05\% level and One-way ANOVA followed by Tukey test (Tukey, 1953). Correlation between NCl of A type NSCs with production of cocoon and also correlation between $\mathrm{NCl}$ of $\mathrm{A}$ type NSCs with ecological factor like temperature were also measured.

\section{Results and Discussion}

In the control earthworm, P. ceylanensis, cocoons (length $97.3 \mathrm{~mm} \pm 0.28$, breadth $3.3 \mathrm{~mm} \pm 0.03$ ) were laid throughout the study. The cocoons of earthworm $P$. ceylanensis were small dark straw in colour, rough, somewhat spindle like with the ends of cocoons extending into tufts of bristles (Fig.1a).

In the cerebral ganglia of un-operated control worm, there were two types of NSCs, such as type A and type B (Fig. 2). The type A cells were deeply stained AF positive with colloidal secretion and were present in the dorsal cortical tier. The type $B$ cells were moderately or lightly stained with $\mathrm{AF}$ and had fine to coarse secretary granules and cytoplasmic vacuolations. The type B cells lay in between the tier of type A cells and central fibrous neuropile. The type A and type B NSCs were in different phases of secretory activity.

Body weight of the earthworms following cephalic amputation (sub group II) declined due to loss of body segments and absence of feeding cum casting activities. Regeneration blastema was formed on the $4^{\text {th }}$ day of cephalic amputation (Fig. 1b). With the development of the mouth, body weight increased and casting activity started after the $10^{\text {th }}$ day (Fig. 3b). 'Debrained' $P$. ceylanensis did not lay cocoons upto $30^{\text {th }}$ day of cephalic amputation. From the $31^{\text {st }}$ day of post cerebral amputation, the worms started laying cocoon. On the other hand, in sub group III (posteriorly amputed earthworm), regeneration blastema appeared on the $2^{\text {nd }}$ day and casting activity also started on the $3^{\text {rd }}$ day (after caudal amputation) and following this, body weight of the worms also started to increase. On the $19^{\text {th }}$ day after the posterior amputation earthworms started to produce cocoons, which was 11 days prior to the sub group II , i.e., the anteriorly amputed worms. Earlier production of cocoon in worms with brain in sub group III than the sub group II also supported the role of brain in cocoon production. Delay in production of cocoon in sub group III is probably due to time required for the regeneration of lost body part. Production of cocoon was inhibited in both subgroup II and III at initial days of post amputation because of restoring the lost body parts. Period of reproductive arrest was much shorter in caudal amputed worms (subgroup III) than the anteriorly amputed ones (subgroup II) as the former already had the vital machineries such as cerebral and subesophageal ganglia for regulating reproductive function, whereas, the latter had to regenerate first the brain and subesophageal ganglion at a functional state so as to set the reproductive cycle.

Durchon (1967) also reported that after excision of cerebral ganglion in earthworm Allolobophora terrestris there was immediate arrests of egg (cocoon) laying, with a loss of weight and secondary sex characteristics, such as the clitellum and tubercula pubertatis and after 8 weeks when the cerebral ganglion was regenerated, egg laying started again which was 

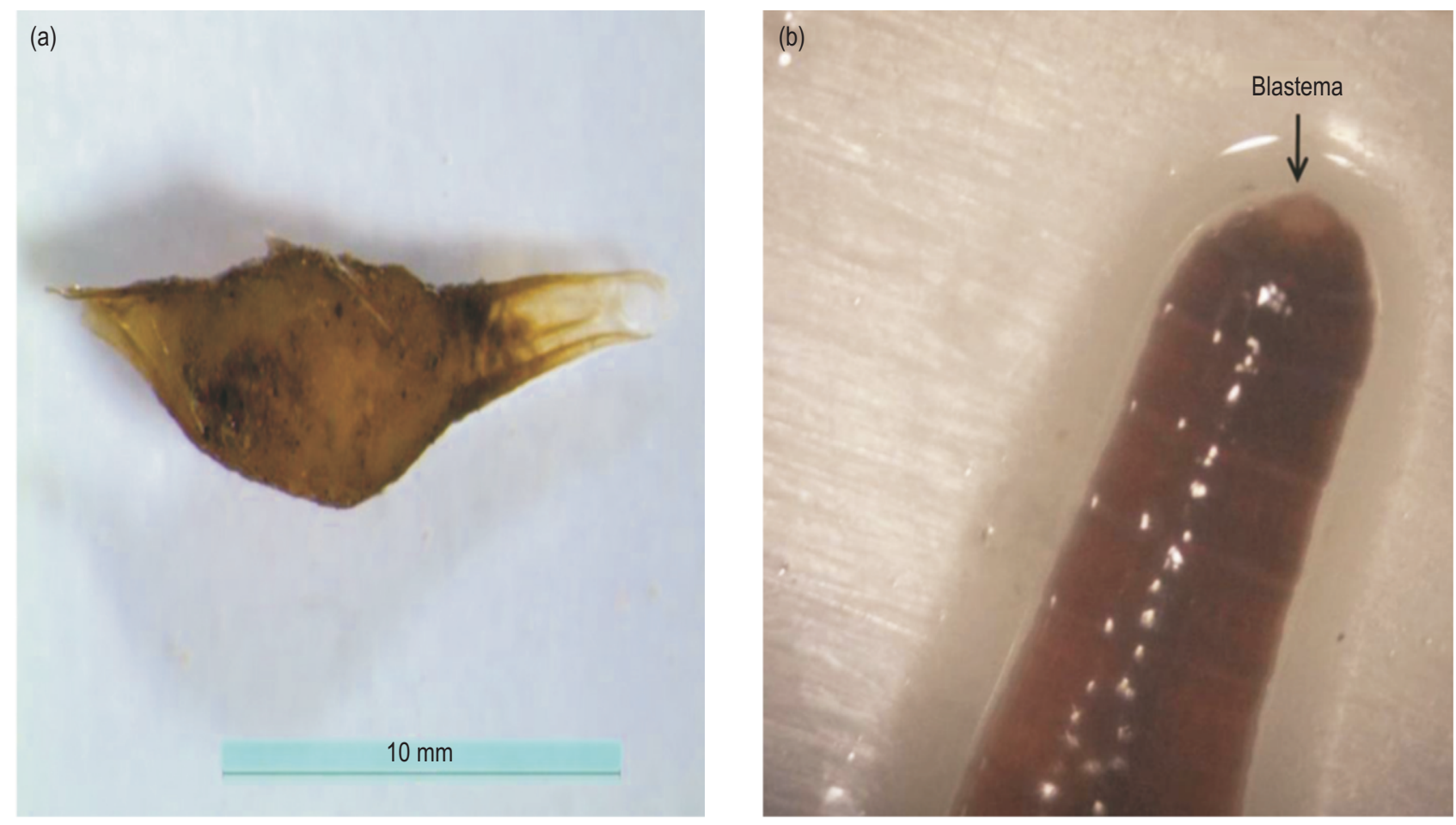

Fig. 1 : Showing (a) cocoon of Perionyx ceylanensis. Note bristle at the terminal part of cocoon and (b) Regeneration blastema in P. ceylanensis.

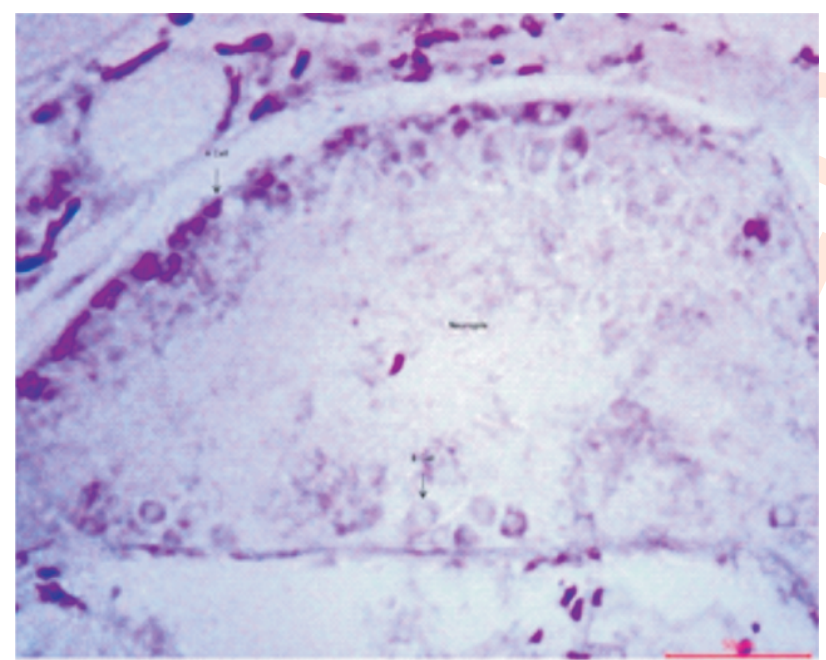

Fig. 2: Control section of cerebral ganglion showing disposition of A type and B type NSCs.

quite similar to the present findings. He further reiterated that when larger portions of the CNS are removed, longer period of reproductive arrest occurred. Jamieson (1981) also advocated the fact that there is an evidence of gross regression of developing gametes during the early phases of cephalic regeneration which supports our present findings. Recently, Okrzesik et al. (2013) confirmed the fact that brain-derived neurosecretion modulates the neural regeneration and reproduction which corroborates with the present findings. This indicates that 'brain' is quite essential for the earthworms to conjugate and cocoon production. Furthermore, external factors like temperature $\left(26-28^{\circ} \mathrm{C}\right)$, food supply in the form of cow dung rich in bacteria and the presence of dim light were favorable for regeneration of cerebral ganglia (in the $3^{\text {rd }}$ segment) followed by conjugation and subsequent cocoon laying.

Rudimentary cerebral ganglia with large numbers of undifferentiated and CAHP positive cells appeared on the $4^{\text {th }}$ day after cephalic amputation (Fig. 3a). The 20 days old regenerated cerebral ganglia was larger in size than those of preceding days with well vascularization and cortical tier of numerous CAHP positive $B$ cells (Fig. $3 \mathrm{c}$ ). On the $31^{\text {st }}$ day with initiation of cocoon production, deeply stained AF positive type ANSCs first appeared in the dorso-lateral part of the regenerated cerebral ganglia (Fig. $3 d)$. This indicates that the $A$ cells are responsible for cocoon generation in earthworm. A few extra cerebral AF positive NSCs appeared in the 31st day regenerated cerebral ganglion (Fig. 3d). In spite of appearance of well formed brain on the $20^{\text {th }}$ day of cerebral regeneration, delay to start cocoon production was due to time needed for reconstruction of functional blood vascularization in regenerated brain (Tombes, 1970) and also late appearance of AF positive A type cells in the regenerated cerebral ganglia of earthworm (Banik et al., 2020). 

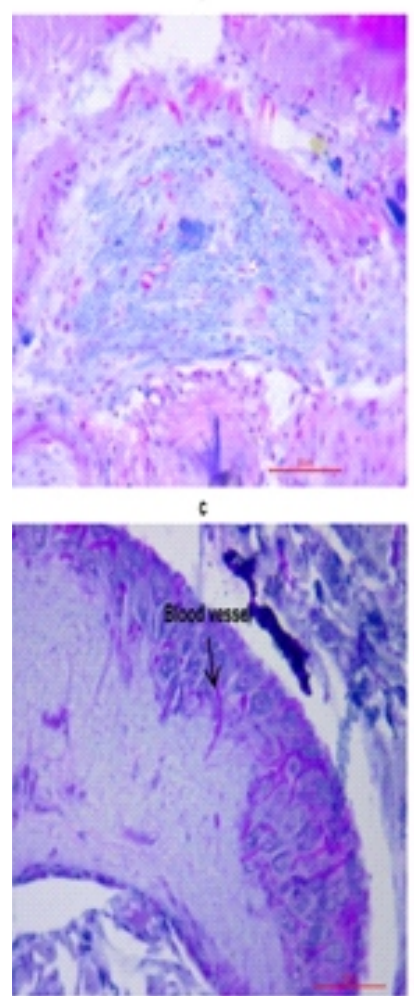

Fig. 3 : Section showing regenerating brain on different days a. 4 days regenerated rudimentary 'brain' with mass of undifferentiated CAHP positive cells. Note appearance of phloxinophilic blood vessel. Also note section of body wall above and pharyngeal wall below the section of 'rudimentary brain'. b. Appearance of CAHP positive cells on $10^{\text {th }}$ days 'regenerating brain'. c. $20^{\text {th }}$ days regenerated brain with disposition of phloxynophilic blood vessels and CAHP positive presumptive B types cells. d. Brain after laying of cocoon. Note full grown 'brain' with well differentiated AF positive type Aand type B NSCs. Note type A and type B NSCs. Arrow outside the brain showed extra cerebral AF positive neurosecretory cells.

Cerebral histological profiles of control earthworm, $P$. ceylanensis with continuous cocoon production, posterior amputed worms with initiation of cocoon generation from the $19^{\text {th }}$ day and anteriorly amputed earthworm with onset of cocoon production from the $31^{\text {st }}$ day were more or less similar with well differentiated deep stained A cells with distinct secretory activities. Cerebral ganglionic $A$ cells are mainly responsible for cocoon laying is based on the fact that the worms with $20^{\text {th }}$ days regenerated brain had only lightly stained $B$ cells, but when along with $B$ cells, deeply stained A cells appeared on the $31^{\text {st }}$ day of regeneration, earthworms started to lay cocoons. This reflects the function of cerebral A cell in production of cocoon in earthworms. Earlier Golding and Whitle (1977) advocated that the cerebral peptidergic type A NSCs are associated in the process of reproduction in earthworm which supports our present findings.

In group II earthworm $P$. ceylanensis, cocoons were laid throughout the year with seasonal fluctuations in number. Mean cocoon production per worm was significantly $(p<0.05)$ higher during monsoon period (44.38 \pm 6.03$)$ than during summer (11.17 $\pm 1.25)$ and winter $(3.83 \pm 1.74$ )(Table1) when mean RT was (23.55 ${ }^{\circ} \mathrm{C}, 29.86{ }^{\circ} \mathrm{C}$ and $30.45^{\circ} \mathrm{C}$ respectively). Seasonal fluctuations in cocoon production among summer and monsoon are probably related to soil moisture and temperature conditions of that year and also the earthworm species that produce cocoon.

Recently, Chaudhuri and Datta (2020) reported a positive correlation between cocoon production and temperature in $P$. ceylanensis that indicates temperature is the limiting factor for cocoon production in this epigeic species. Evans and Guild (1948) observed that the cultures of common Lumbricid species maintained under optimal soil moisture, the number of cocoons produced by each species paralleled closely with the seasonal fluctuations in soil moisture. Edwards and Bohlen (1996) reported fewer cocoon generation during winter was mainly due to sudden decline in temperature and with the increase in temperature during summer condition (May-July) there was great rise of cocoon generation in temperate earthworm which was quite similar to the present findings. Earlier the highest cocoon generation under Indian condition was recorded during monsoon when soil moisture condition was optimum (Dash and Senapati, 1982) which corroborates with the present findings of maximum cocoon generation during wet season (Table1) under laboratory condition. Chaudhuri and Bhattacharjee (2011) also recorded the highest production of cocoon in eight tropical earthworm species

Table 1 : Seasonal variation of cerebral neurosecretory cell (A cell) during cocoon production

\begin{tabular}{|c|c|c|c|c|c|c|c|c|}
\hline \multirow[t]{2}{*}{ Seasons } & \multicolumn{6}{|c|}{ A cell } & \multirow{2}{*}{$\begin{array}{l}\text { Mean } \\
\text { number of } \\
\text { cocoon } \\
\text { production/ } \\
\text { worm }\end{array}$} & \multirow{2}{*}{$\begin{array}{l}\text { Mean room } \\
\text { temper- } \\
\text { ature }\left({ }^{\circ} \mathrm{C}\right)\end{array}$} \\
\hline & $\begin{array}{l}\text { Cell length } \\
(\mu \mathrm{m})\end{array}$ & $\begin{array}{l}\text { Cell diameter } \\
(\mu \mathrm{m})\end{array}$ & $\begin{array}{l}\text { Cell volume } \\
\left(\mu \mathrm{m}^{3}\right)\end{array}$ & $\begin{array}{l}\text { Nuclear } \\
\text { diameter } \\
(\mu \mathrm{m})\end{array}$ & $\begin{array}{l}\text { Nuclear volume } \\
\left(\mu \mathrm{m}^{3}\right)\end{array}$ & $\begin{array}{l}\text { Nucleocyto- } \\
\text { plasmic index }\end{array}$ & & \\
\hline Winter & $10.25 \pm 0.36$ & $6.77 \pm 0.42$ & $86.77 \pm 11.79^{a^{*}}$ & $3.58 \pm 0.25$ & $31.71 \pm 7.32^{\mathrm{a}}$ & $0.7817 \pm 0.23^{\mathrm{a}}$ & $3.83 \pm 1.74^{\mathrm{a}}$ & $23.55 \pm 0.73$ \\
\hline Summer & $18.32 \pm 0.74$ & $11.56 \pm 0.63$ & $454.13 \pm 60.89^{b}$ & $6.92 \pm 0.3$ & $197.89 \pm 28.82^{b}$ & $1.2489 \pm 0.218^{b}$ & $11.17 \pm 1.25^{b}$ & $29.86 \pm 0.43$ \\
\hline Monsoon & $16.87 \pm 0.47$ & $10.02 \pm 0.51$ & $291.54 \pm 38.74^{c}$ & $6.24 \pm 0.19$ & $133.87 \pm 11.64^{c}$ & $2.43 \pm 0.71^{\circ}$ & $44.38 \pm 6.03^{c}$ & $30.45 \pm 0.46$ \\
\hline
\end{tabular}

${ }^{*}$ Dissimilar letter in column indicate significance difference $(p<0.05)$ 

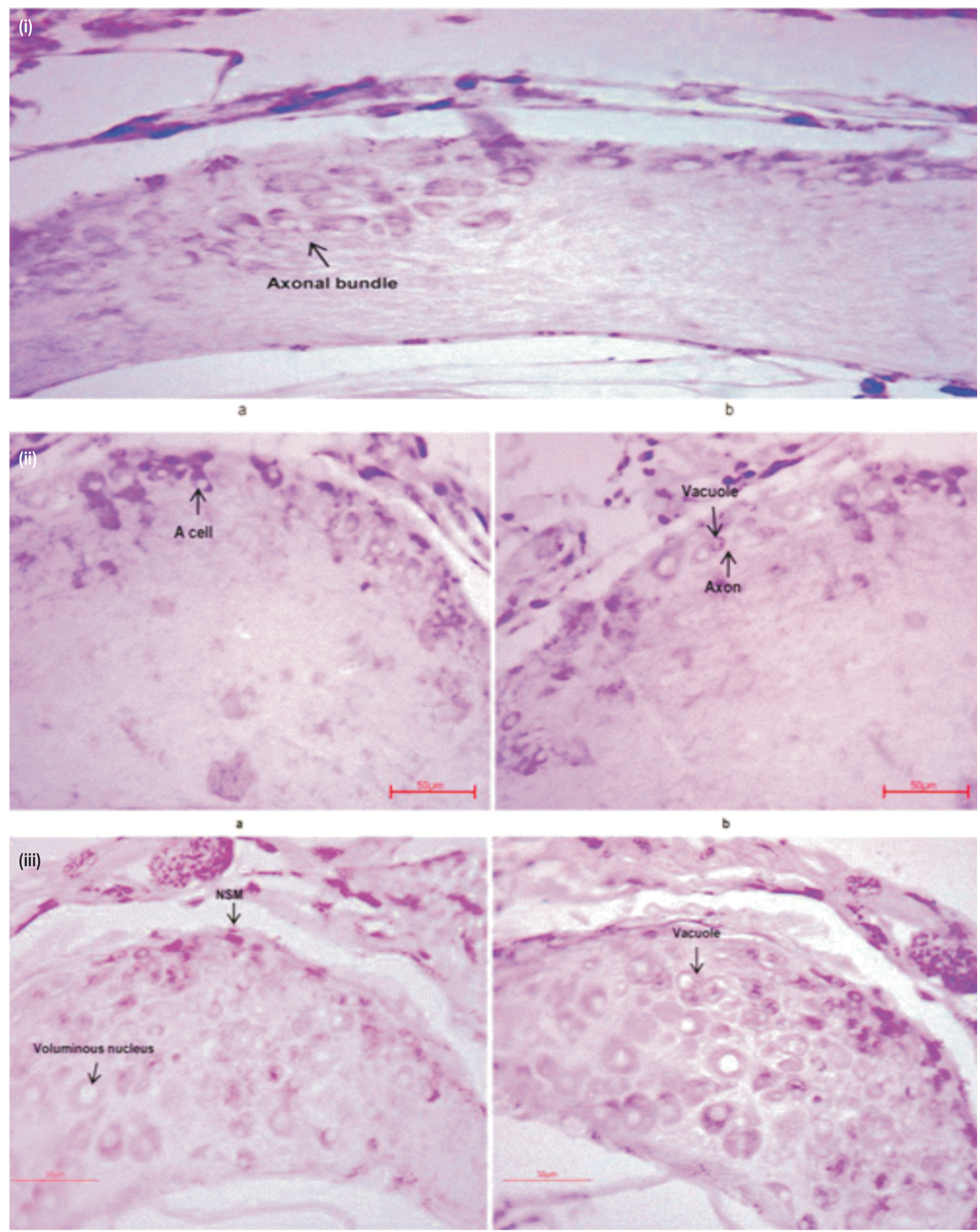

Fig. 4 : Section showing (i) faintly AF positive NSCs in the 'winter brain'; (ii) 'summer brain' of earthworm (a,b) with NSCs in different phases of secretion and (iii) 'monsoon brain' also showing different phases of secretory activity of NSCs (a,b). 
$Y=26.842+0.669291 X$

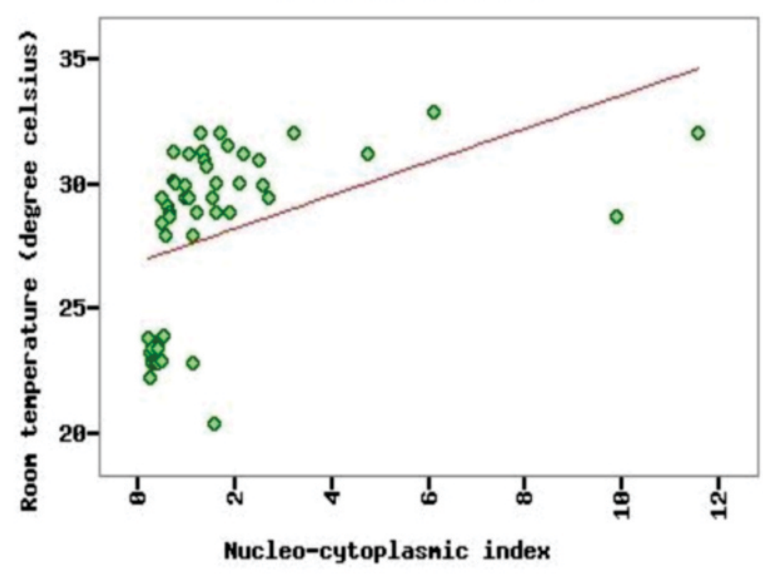

b

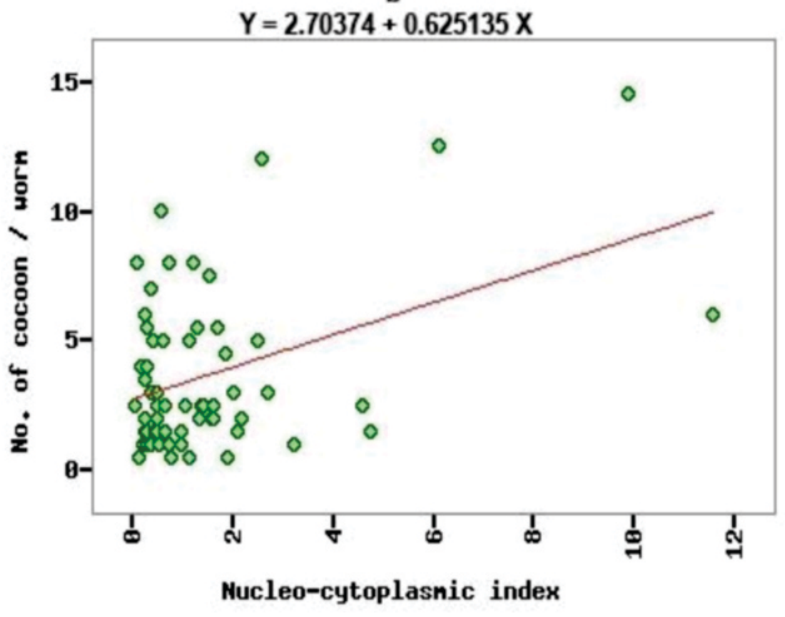

Fig. 5 : Relation between nucleo-cytoplasmic index $(\mathrm{NCl})$ of cerebral A type cell with room temperature $\left({ }^{\circ} \mathrm{C}\right)(\mathrm{r}=0.416, p<0.05)(\mathrm{a})$ and number of cocoon produced per worm $(r=0.423, p<0.05)(b)$.

during monsoon season compared to summer and winter. Abiotic factors like light, soil moisture, temperature (Chaudhuri and Datta, 2020), quality of diet (Datta and Chaudhuri, 2020) and biological factors viz, age, sexual maturity (Parthasarathi and Ranganathan, 2000) and earthworm biomass (Okrzesik et al., 2013; Chaudhuri and Datta, 2020) are also other important factors that influence cerebral neurosecretory cells for the production of cocoon.

Cerebral histological studies have revealed that during winter, brain of $P$. ceylanensis the NSCs irrespective of their types there showed the presence of cytoplasmic vacuoles and low contents of AF positive secretion (Fig. 4 i). In both summer 'brain' and monsoon 'brain', type A and type B NSCs were well differentiated and in different phase of secretory activities (Fig. 4 ii, iii). There were abundance cytoplasmic vacuoles in A type NSCs in both monsoon and summer 'brain'. Visual studies revealed greater increase in the number of type A cells in the monsoon 'brain' than in the summer 'brain' in P. ceylanensis. Rise in the number of cerebral A type cells of $P$. ceylanensis along with axonal transport, cytoplasmic vacuolations and increase in their $\mathrm{NCl}$ during both summer and monsoon (Fig. 4 ii, iii) indicates utilization of neurosecretory material (NSM) and also revealed hyperactivity of NSCs during cocoon production. This hyperactivity of cerebral A type NSCs reflects its role in the production of cocoon. Lowest $\mathrm{NCl}$ along with low content neurosecretory materials of cerebral A type cell of $P$. ceylanensis indicates their lowest neurosecretory activity to generate fewer cocoons which was recorded in the winter 'brain'. Interestingly, seasonal fluctuations in the activity of A type cell coincided with the seasonal variation of cocoon production in earthworm. This revealed the possible role of cerebral $A$ type cell in cocoon production.
Cerebral A cell showed a distinct secretory cycle which were harmonized with the reproductive cycle of earthworm and similar phenomenon was also observed in leach, Theromyzon rude (Hagadorn,1962) and in male crab, Uca (celuca) lactea annulipes (Jadhav et al., 2001). According to Tombes (1970), copulation and oviposition in earthworms coincide with cytoplasmic vacuolation of the cell body resulting in reduction in the amount of NSM in the cell body and also in axons, which further supports the present findings. Recently, Banik et al. (2020) advocated the function of cerebral A type and B type NSCs in the process of copulation in epigeic earthworm E. fetida, which was followed by production of cocoons.

Cell volume, nuclear volume and $\mathrm{NCl}$ of cerebral neurosecretory A cells in $P$. ceylanensis during summer and monsoon were significantly higher $(p<0.05)$ than in winter (Table 1). $\mathrm{NCl}$ indicates cellular activity (Siew, 1965). There was a positive and significant $(p<0.05)$ relationship between $\mathrm{NCl}$ of NSCs with room temperature $(r=0.416)$ as well as with cocoon production $(r=0.423)$ (Fig. $5 a, b)$. This indicates that cocoon generation in earthworm is influenced by temperature as well as $\mathrm{NCl}$ of cerebral $\mathrm{A}$ cell. A positive relationship between $\mathrm{NCl}$ of A type cells and cocoon production indicates the possible role of cerebral type A NSCs in cocoon production. Future immune-cytochemical studies will confirm the role of cerebral type A NSCs in earthworm cocoon production.

In conclusion, the present study provides some evidence that 'brain' and its A type neurosecretory cells play a major role in cocoon production in earthworms. Based on the present research work, future research can be extended with manipulation of cerebral ganglia in earthworm species in order to improve the sexual maturity in earthworms and their cocoon production which 
are essential factors in vermiculture technology.

\section{Acknowledgment}

The authors express their sincere thanks to the HOD, Department of Zoology, Tripura University for providing laboratory facilities.

\section{Add-on Information}

Authors' contribution: P.S. Chaudhuri: Made the design, concept, title of the paper, necessary corrections and improvement of paper, R. Datta: Carried out the whole work, made statistical analysis and written the paper

Research content: The research content of manuscript is original and has not been published elsewhere.

\section{Ethical approval: Not applicable}

Conflict of interest: The authors declare that there is no conflict of interest.

\section{Data from other sources: Not applicable}

Consent to publish: All authors agree to publish the paper in Journal of Environmental Biology.

\section{References}

Banik, D., P.S. Chaudhuri and A. Bhattacharjee: Cytomorphological changes in the cerebral and ventral ganglionic neurosecretory cells during copulation in epigeic earthworms. Eur. J. Biol Res., 10, 207-216(2020)

Borrione, P., L. Fabiani, S. Geuna and M.G. Giacobini-Robecchi: Nucleoplasmic index variability in dorsal root ganglion neurons of the lizard (Podarcis sicula) during neuronal hypertrophy. Neurosci. Lett., 233,1-4(1997).

Bhattacharjee, G. and P.S. Chaudhuri : Cocoon production, morphology, hatching pattern and fecundity in seven tropical earthworm species- a laboratory based investigation. J. Biosci., 27, 283-294 (2002)

Chaudhuri, P.S. and R. Datta: Studies on cocoons of three epigeic earthworm species Perionyx excavatus (Perrier), Perionyx ceylanensis (Michaelsen) and Eudrilus eugeniae (Kinberg) with SEM observations. Proc. Zool. Soc., 73,430-440 (2020).

Chaudhuri, P.S.: Earthworm Technology - A promising tool for second green revolution. In: Advances in waste management (Eds.: A.S. Kalamdhad., J. Singh and K. Dhamodharan). Springer Nature Singapore Pvt. Ltd., Singapore, p.1-15 (2019).

Chaudhuri, P.S. and S. Bhattacharjee: Reproductive biology of eight tropical earthworm species of rubber plantations in Tripura, India. Trop. Ecol., 52, 49-60 (2011).

Chaudhuri, P.S.: Vermiculture and vermicomposting as biotechnology for conversion of organic wastes into organic fertilizer and animal protein and organic fertilizer. Asian J. Microbiol. Biotech. Envirin. Sci., 7, 359-370(2005).
Cosín, D.J.D., M. Novo and R. Fernández: Reproduction of Earthworms. In: Sexual Selection and Parthenogenesis (Ed.: A. Karaca) Springer, Berlin, Heidelberg., pp.69-84(2011).

Dash, M.C. and B.K. Senapati: Environmental regulation of Oligochaeta reproduction in tropical pastures. Pedobiologia, 23, 270271(1982).

Datta, R. and P.S. Chaudhuri: Vermiculture of native earthworm Perionyx ceylanensis in different experimental diets. UP. J. Zool., 41, 116$122(2020)$

Debnath, S. and P.S. Chaudhuri: Cocoon biology of earthworms of waste deposit sites of Tripura (India). UP. J. Zool., 41, 32-46(2020).

Dhar, S. and P.S. Chaudhuri: Earthworm communities in paddy (Oryza sativa) fields of West Tripura (India). Proc. Zool. Soc., 73, 273-284 (2020).

Durchon, M.: L'Endocrinologie des vers et des Mollusques. $1^{\text {st }}$ Edn., Masson \& Cie, Paris (1967).

Edwards, C.A. and P.J. Bohlen: Biology and Ecology of Earthworms. $3^{\text {rd }}$ Edn., Chapman and Hall, London (1996).

Edwards, C.A., N.Q. Arancon and R. Sherman: Vermiculture Technology. Taylor \& Francis Group, Boca Raton, London, New York (2011).

Evans, A.C. and W. J. Mc. L. Guild: Studies on the relationships between earthworms and soil fertility. IV. On the life cycles of some British Lumbricidae. Ann. Appl. Biol., 35, 471-484 (1948).

Golding, M.L. and A.C. Whittle: Neurosecretion and related phenomenon in Annelids. Int. Rev. Cytol., Academic Press, New York, pp.189292(1977)

Hagadorn, I.R.: Neurosecretory phenomena in the leech, Theromyzon rude. In: Neurosecretion (Eds.: H. Heller and R.B. Clark). Academic Press, NY., p.313-321 (1962).

Jadhav, S., M.G. Rangunathan and M. Deecaraman: Changes in the neurosecretory cells of the brain and thoracic ganglion of male crab, Uca (celuca) lactea annulipes with respect to seasons. J. Environ. Biol., 22, 311-314(2001).

Jamieson, B.G.M.: The Ultrastructure of the Oligochaeta. Academic press, London(1981)

Karmegam, N. and T. Daniel: Growth, reproductive biology and life cycle of the vermicomposting earthworm, Perionyx ceylanensis Mich. (Oligochaeta: Megascolecidae). Bioresour. Technol., 100, 47904796 (2009).

Okrzesik, J., N.K. Trojanowska, A. Jozkowicz, A.J. Morgan and B. Plytycz: Reversible inhibition of reproduction during regeneration of cerebral ganglia and celomocytes in the earthworm Dendrobaena veneta. Invertebrate Surviv. J., 10,151-161(2013).

Parthasarathi, K. and L.S. Ranganathan: Influence of pressmud on the development of the ovary, oogenesis and the neurosecretory cells of the earthworm Eudrilus eugeniae (Kingberg). Afr. Zool., 35, 281$286(2000)$.

Siekierska, E.: The structural of the ovary and oogenesis in gonadotropin-deprived earthworm, Dendrobaena veneta (Rosa). Zool. Pol., 47, 37-48 (2002)

Siew, Y.C.: The endocrine control of adult reproductive diapause in the chrysomelid beetle Galeruca tanaceti (L.) II. J. Insect Physiol., 11, 463-479 (1965).

Tombes, A.S.: An Introduction to Invertebrate Endocrinology. $1^{\text {st }}$ Edn., Academic Press, New York, USA(1970).

Tukey, J.W.: The problem of multiple comparisons. In: The Collected Works of John W. Tukey VIII. Multiple Comparisons (Ed.: H.I. Braun). Chapman and Hall, New York, USA., pp.1948-1983 (1953).

Zar, J.H.: Biostatistical Analysis. $4^{\text {th }}$ Edn., Prentice Hall, Upper Saddle River, N J, USA(1999) 